\title{
Therapeutic potential of a long acting somatostatin analogue in gastrointestinal diseases
}

Somatostatin, a naturally occurring peptide (Figure), was first discovered more than 20 years ago. ${ }^{12}$ The gastrointestinal tract and pancreas contain more somatostatin than any other organ. ${ }^{3}$ When infused intravenously the hormone modulates numerous gut functions although its exact physiological and biological role are still not fully defined. Administration of somatostatin reduces gastric acid and pancreatic secretion, ${ }^{45}$ small gut transit,${ }^{6}$ absorption of intestinal nutrients ${ }^{7-10}$ and gastrointestinal blood flow. ${ }^{11}$ Gastric emptying is enhanced at low plasma somatostatin concentrations ${ }^{4}$ and inhibited at high concentrations. ${ }^{12}$ The therapeutic application of somatostatin has been limited by its short circulating half-life of about two minutes and the need for parenteral administration. The development of a long acting cyclic octapeptide somatostatin analogue (SMS 201-995, octreotide) (Figure) with a circulating half-life of one to two hours after subcutaneous administration, has therapeutic potential. ${ }^{13}$ It could be of value in gastrointestinal bleeding, intestinal fistulae, the short bowel syndrome, pancreatitis, the dumping syndrome and gut related endocrine tumours.

\section{Gastrointestinal bleeding}

Control of variceal bleeding may be the area of greatest clinical impact. Somatostatin reduces portal pressure,,$^{14}$ hepatic blood flow ${ }^{1+16}$ and azygous

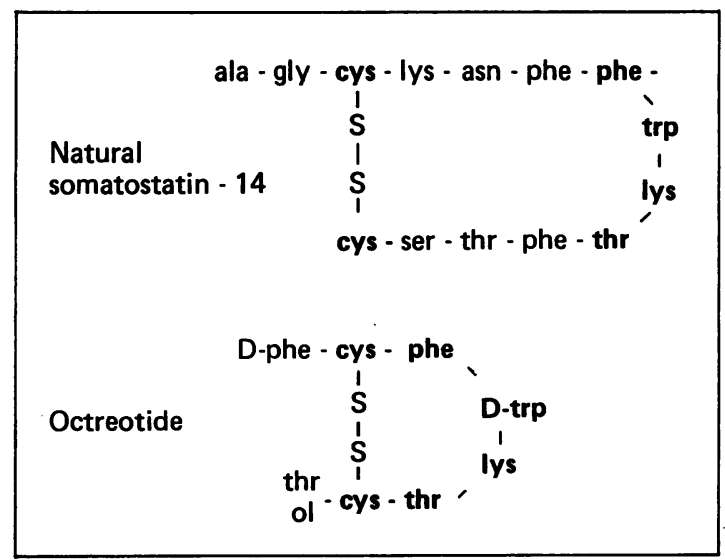

Figure Amino acid sequence of native somatostatin-14 and octreotide. 
blood flow ${ }^{16} 17$ in patients with cirrhosis but reports claiming that it reduces intravariceal pressure ${ }^{18} 19$ have not been confirmed. ${ }^{21}$ Somatostatin infusion has no appreciable effect on systemic haemodynamics ${ }^{1+}$ although with bolus injections of either somatostatin or octreotide there may be transient reductions in heart rate and cardiac output and a rise in mean arterial blood pressure. ${ }^{1619}$

Two controlled clinical trials comparing somatostatin infusion with vasopressin infusion for bleeding oesophageal varices have been reported. Kravetz et $\mathrm{al}^{-1}$ reported that somatostatin infusion $(50 \mu \mathrm{g}$ bolus and $250 \mu \mathrm{g} / \mathrm{h})$ stopped bleeding in $87 \%$ of patients for up to three hours after starting treatment and was as effective as vasopressin for up to $48 \mathrm{~h}$. Jenkins $e t a l^{2}$ found that somatostatin infusion of similar concentrations controlled variceal haemorrhage during the first $18-24 \mathrm{~h}$ in all 10 patients compared with four of 12 treated with vasopressin infusion $(p=0.003)$. In both studies major and minor complications of treatment were less with somatostatin than with vasopressin. Comparison of somatostatin with combined vasopressin and glyceryl trinitrate has not been reported.

McKee et $a l^{23}$ have compared variceal tamponade and octreotide infusion $(25 \mu \mathrm{g} / \mathrm{h})$ in patients with acute variceal bleeding. Bleeding control was similar in both groups at four and $48 \mathrm{~h}$ after the start of treatment. Five deaths occurred in the 20 patients treated with variceal tamponade whereas all 20 patients treated with octreotide survived $(p<0 \cdot 047)$. In a similar study somatostatin infusion proved superior to variceal tamponade in controlling haemorrhage and produced fewer complications..$^{24}$

Thus, octreotide is an effective treatment for the management of acute variceal bleeding, controlling approximately $90 \%$ of bleeding episodes in the first four hours. Its lack of side effects, ease of administration and patient acceptability should ensure that it becomes the treatment of choice for the initial management of variceal haemorrhage before definitive treatment with sclerotherapy or oesophageal transection. If subcutaneous administration of octreotide is as effective as infusion, the drug could make a useful contribution to early, pre hospital management of bleeding varices.

Somatostatin infusion reduces gastric and splanchnic blood flow. ${ }^{125}$ Three controlled studies with small numbers of patients indicated that somatostatin infusion was superior to placebo and $\mathrm{H}_{2}$-receptor antagonists in controlling bleeding from peptic ulcers..$^{26-28}$ In a large placebo controlled study with over 300 patients, somatostatin infusion in each arm showed no benefit when compared with placebo in the treatment of acute haematemesis and melaena. ${ }^{29}$ In a condition where there is a $70-80 \%$ spontaneous cure rate, drug therapy has to be either extremely effective or directed towards those most likely to have persistent bleeding. Somatostatin and octreotide could be of benefit in a highly selected group of patients with gastrointestinal bleeding who are at high risk of rebleeding as defined by clinical and endoscopic criteria.

\section{Fistulae and the short bowel syndrome}

In several open trials, relatively high doses of either somatostatin infusion or eight hourly subcutaneous octreotide close nearly $80 \%$ of enterocutaneous fistulae within an average of four to five days. ${ }^{31-34}$ One group have reported much poorer results. ${ }^{35}$ Somatostatin or octreotide was given in addition to 
conventional treatment with total parenteral nutrition (TPN). Somatostatin and octreotide were least effective in the presence of continuing infection or inflammatory activity, cancer or distal intestinal obstruction. There has been no report of a controlled trial with octreotide in the management of enterocutaneous fistulae so that it is uncertain whether the administration of octreotide with TPN is significantly superior to TPN alone.

Open trials of both somatostatin infusion ${ }^{36}{ }^{37}$ and octreotide $0 \cdot 1 \mathrm{mg}$ to 0.6 mg per day ${ }^{38}{ }^{39}$ report accelerated closure of approximately $50-80 \%$ of pancreatic fistulae occurring after pancreatitis, subtotal pancreatectomy or surgical trauma. Pancreatic duct obstruction, malignancy, or unresolved sepsis should be excluded before starting octreotide.

Octreotide increased water, sodium and calorie absorption in patients with the short bowel syndrome dependent on longterm TPN or parenteral fluid and electrolyte supplementation. ${ }^{40}$ This reduced the daily requirements of parenteral supplementation and was discontinued completely in one patient. $^{41} 42$

\section{Pancreatitis}

Both somatostatin and octreotide prevent the occurrence and reduce the severity of bile induced pancreatitis in an experimental animal model..$^{434}$ Octreotide did not confer benefit in animals with diet induced pancreatitis. ${ }^{45}$ In open trials in humans somatostatin infusion appeared beneficial in the treatment of acute pancreatitis $\mathrm{s}^{46}$ but controlled trials although showing a favourable trend have failed to show a clearcut benefit. ${ }^{4849}$ Future trials will need larger numbers of patients, including those with severe pancreatitis and should incorporate a severity based stratification before randomisation.

Somatostatin infusion may reduce pain, pancreatic swelling and hyperamylasaemia after ERCP ${ }^{50-52}$ but as severe pancreatitis only occurs in a few patients, it is premature to advocate the routine prophylactic use of octreotide during this procedure.

\section{Irritable bowel syndrome}

An intriguing case report described relief of irritable bowel syndrome (IBS) symptoms in a patient receiving subcutaneous somatostatin for acromegaly. ${ }^{53}$ The history of irritable bowel predated that of the acromegaly. The patient had received numerous previous treatments for IBS and acromegaly, none of which had produced relief of her symptoms, so a placebo effect was thought unlikely. It was suggested that a deficiency of somatostatin may be involved in the pathogenesis of IBS.

There is a trend towards reduced fasting and peak postprandial plasma concentrations of somatostatin in patients with 'diarrhoea' predominant IBS. ${ }^{54}$ The pathogenetic significance of this finding remains obscure but therapeutic use of octreotide in the IBS is a tantalising possibility.

\section{Dumping syndrome}

Octreotide and somatostatin have been used in the treatment of the dumping syndrome because of their effects on gastric emptying, intestinal 
secretion and glucose tolerance. With dumping provocation tests both somatostatin and octreotide abolish or reduce early and late dumping symptoms associated with hypovolaemia and hypoglycaemia, respectively. ${ }^{55-59}$ Although in the long-term some patients receive benefit from octreotide many others are unable to tolerate the drug because of the occurrence of diarrhoea. ${ }^{601}$ Paradoxical hypoglycaemia has been reported in patients with dumping syndrome after starting octreotide therapy due to suppression of glucagon as well as insulin secretion.

\section{Gut related endocrine tumours}

Somatostatin and octreotide have been used to treat digestive tract associated endocrine tumours such as VIPomas, carcinoid tumours, gastrinomas, insulinomas and glucagonomas. The clinical manifestations of these slow growing neoplasms are due to mass effects of the tumours and metastases and to secretion of biologically active hormones. If the tumours are resectable, surgery is indicated. Chemotherapy with streptozotocin and 5-flurouracil is not only toxic but also has a low tumour response rate.

There have been sporadic individual reports of tumour regression in $\operatorname{man}^{62-a+}$ and in experimental animals ${ }^{65}{ }^{66}$ but as yet there is no convincing evidence to indicate that octreotide produces clinically important tumour shrinkage. Nevertheless octreotide has produced dramatic symptomatic benefit for many patients by suppressing hormone secretion. Patients with VIPomas and torrential life threatening diarrhoea have had complete remission of their symptoms with octreotide and have been maintained longterm on twice daily subcutaneous injections without complications. ${ }^{67}{ }^{68}$

High doses of subcutaneous octreotide up to $250 \mu \mathrm{g}$ three times a day can be effective in relieving symptoms of the carcinoid syndrome. ${ }^{6971}$ Low doses produce little or no benefit. ${ }^{71-73}$ Although producing symptom relief, the effect of octreotide on 5-HIAA secretion from these tumours is variable suggesting that peripheral actions are important in the therapeutic effect. ${ }^{71}$ Somatostatin has been used in patients with carcinoid tumours to prevent perioperative hypotension. ${ }^{74}$

In patients with gastrinomas a single subcutaneous injection of octreotide can suppress gastrin secretion for up to $18 \mathrm{~h} .^{75}$ Longterm symptomatic improvement in patients with the Zollinger-Ellison syndrome has also been described $^{76}$ but with the advent of omeprazole there is a limited role for octreotide. Benefit from octreotide has been reported in patients with insulinomas $\mathrm{s}^{778}$ and glucagonomas ${ }^{740}$ although this response is not as clearcut as with other tumours. ${ }^{8182}$

In the longterm management of these endocrine tumours, drug associated side effects are uncommon. Pain at the site of octreotide injection is frequent but generally acceptable. Biochemical glucose intolerance rarely progresses to overt diabetes. Steatorrhoea may occur with high doses. Rebound hypersecretion of tumour hormone may occur with drastic sequelae if octreotide therapy is discontinued ${ }^{838+}$ and paradoxical hypoglycaemia has been described on starting therapy in patients with insulinomas. ${ }^{\mathrm{x}}$

\section{Conclusion}

Octreotide has been used therapeutically in a wide spectrum of gastro- 
intestinal conditions but further work is required before the exact indications for its use are fully defined. It may be of value in patients with bleeding oesophageal varices, enterocutaneous fistulae and gut related endocrine tumours. The possibility that octreotide may benefit irritable bowel patients needs further exploration. The development of an orally active somatostatin analogue is underway and is likely to be of great value.

LUKE J D O'DONNELL AND MICHAEL J G FARTHING

Department of Gastroenterology,

St Batholomew's Hospital,

London

MJGF is a Wellcome Trust Senior Lecturer and gratefully acknowledges financial support by the Wellcome Trust.

\section{References}

1 Brazeau R, Vale W, Burgus R, et al. Hypothalamic polypeptide that inhibits the secretion of immunoreactive pituitary growth hormone. Science 1973; 173: 77-9.

2 Krulich L, Dhariwal APS, McCann SM. Stimulatory and inhibitory effects of purified hypothalamic extracts on growth hormone release from rat pituitary in vitro. Endocrinology 1968; 83: 783-90.

3 Arimura A. Sato H, Dupont A, Nishi N, Schally AV. Somatostatin: abundance of immunoreactive hormone in rat stomach and pancreas. Science 1975; 189: 1007-9.

4 Mogard MM, Maxwell V, Wong H, Reedy TJ, Sytnik B, Walsh JH. Somatostatin may not be a hormonal messenger of fat-induced inhibition of gastric functions. Gastroenterology 1988; 94: 405-8.

5 Dollinger HC, Raptis S, Pfeiffer EF. Effects of somatostatin on exocrine and endocrine pancreatic function stimulated by intestinal hormones in man. Horm Metab Res 1976; 8: 74-8.

6 Fuessl HS, Carolan G, Williams G, Bloom SR. Effect of a long-acting somatostatin analogue (SMS 201-995) on post-prandial gastric emptying of ${ }^{\omega_{1} / m}$ Tc-Tin colloid and mouthto-caccum transit time in man. Digestion 1987; 36: 101-7.

7 Pointer H, Hengle G, Bayer PM, Flegel U. Somatostatin reduces the rise in plasma triglycerides after a test meal of neutral fat. Scand J Gastroenterol 1976; 11: [Suppl 41]: 51 .

8 Wahren J, Felig P. Influence of somatostatin on carbohydrate disposal and absorption in diabetes mellitus. Lancet 1976; ii: 1213-6.

9 Evenson D, Hanssen KF, Berstrad A. The effect on intestinal calcium absorption of somatostatin in man. Scand J Gastroenterol 1978; 13: 449-51.

10 Goldberg DJ, Walesby M, Sherwin RS. Effect of somatostatin on the plasma amino acid response to ingested protein in man. Metabolism 1979; 28: 866-73.

11 Price BA. Jaffe BM, Zinner MJ. Effect of exogenous somatostatin infusion on gastrointestinal blood flow and hormones in the conscious dog. Gastroenterology 1985; 88: 80-5.

12 Bloom SR, Ralphs DN, Besser GM, et al. Effects of somatostatin on motilin levels and gastric emptying (Abstract). Gut 1975; 16: 834.

13 Bauer W, Briner U, Doepfner W, et al. SMS 201-995: A very potent and selective octapeptide analogue of somatostatin with prolonged action. Life Sci 1982; 31: 1133-40.

14 Bosch J, Kravetz D, Rodes J. Effects of somatostatin on hepatic and systemic hemodynamics in patients with cirrhosis. Gastroenterology 1981; 80: 518-25.

15 Eriksson LS, Law DH, Sato Y, Wahren J. Influence of somatostatin on splanchnic haemodynamics in patients with liver cirrhosis. Clin Physiol 1984; 4: 5-11.

16 Mastai R, Bosch J, Navasa M, et al. Effect of continuous infusion and bolus injection of somatostatin on azygos blood flow and hepatic and systemic haemodynamics in patients with portal hypertension. J Hepatol 1986; 3: [suppl 1]: S53.

17 Bosch J, Mastai R, Kravetz D, Bruix J, Rigau J, Rodes J. Measurement of azygos venous blood flow in the evaluation of portal hypertension in patients with cirrhosis of the liver. J Hepatol 1985; 1: 125-39.

18 Clements D. Rhodes JM, Elias E. Effect of somatostatin on oesophageal variceal pressure assessed by direct measurement. $J$ Hepatol 1986; 2: 262-6.

19 Jenkins SA, Baxter JN, Corbett WA. Shicld R. Effects of a somatostatin analogue SMS 201-995 on hepatic haemodynamics in the pig and on intravariceal pressure in man. $\mathrm{Br} J$ Surg 1985; 72: 1009-12. 
20 Kleber G, Sauerbruch T, Fischer G, Paumgartner G. Somatostatin does not reduce oesophageal variceal pressure in liver cirrhotics. Gut 1988; 29: 153-6.

21 Kravetz D, Bosch J, Teres J, Bruix J, Rimola A, Rodes J. Comparison of intravenous somatostatin and vasopressin infusions in treatment of acute variceal hacmorrhage. Hepatology 1984; 4: 442-6.

22 Jenkins SA, Baxter JN, Corbett W, Devitt P, Ware J, Shields R. A prospective randomized controlled clinical trial comparing somatostatin and vasopressin in controlling acute variccal bleeding. Br Med J 1985; 290: 275-8.

23 McKee RF, Garden OJ, Anderson JR, Carter DC. A long acting somatostatin analogue in the management of bleeding from oesophageal varices. (Communication to the Association of Surgeons of Great Britain and Ireland, 1989). (In press).

24 Avgerinos A, Klonis C. Rekoumis G, Gouma P. Papadimitriou N. Controlled trial of somatostatin and balloon tamponade in blecding esophageal varices. [Abstract] Gastroenterology 1989; 96: A18.

25 Sonnenberg A, West C. Somatostatin reduces gastric blood flow in normal subjects but not in patients with cirrhosis of the liver. Gut 1983; 24: 148-53.

26 Corragio F, Scarpato P. Spina M, Lombardi S. Somatostatin and ranitidine in the control of iatrogenic haemorrhage of the upper gastrointestinal tract. Br Med J 1984; 289: 224.

27 Kayasseh L, Gyr K, Keller U, Stalder GA, Wall M. Somatostatin and cimetidine in pepticulcer hacmorrhage. Lancet 1980; i: 844-6.

28 Magnusson I, Ihre T, Johansson C, Seligson U, Torngren S, Uvnas-Moberg K. Randomized double blind trial of somatostatin in the treatment of massive upper gastrointestinal haemorrhage. Gut 1985; 26: 221-6.

29 Somerville KW, Davies JG, Hawkey CJ, Henry DA, Hine KR, Langman MJS. Somatostatin in the treatment of haematemesis and melaena. Lancet 1985; i: 130-2.

30 Di Costanzo J, Cano N, Martin J. Somatostatin in persistent gastrointestinal fistula treated by total parenteral nutrition. Lancet 1982 ; ii: 338-9.

31 Hild P, Dobroschke J, Henneking K, Ricck B. Treatment of enterocutaneous fistulas with somatostatin. Lancet 1986; ii: 626.

32 Geerdsen JP, Pedersen VM, Kjaergard H. Small bowel fistulas treated with somatostatin: preliminary results. Surgery $1986 ; 100: 811-4$.

33 Nubiola-Calonge P, Badia JM, Sancho J, Gil MJ, Segura M, Sitges-Serra A. Blind evaluation of the effect of octreotide (SMS 201-995), a somatostatin analogue, on small bowel fistula output. Lancet 1987 ; ii: $672-4$.

34 Di Costanzo J, Cano N, Martin J, et al. Treatment of external gastrointestinal fistulas by a combination of total parenteral nutrition and somatostatin. JPEN 1987; 11: 465-70.

35 Kingsnorth AN, Moss JG, Small WP. Failure of somatostatin to accelerate closure of enterocutaneous fistulae in patients receiving total parenteral nutrition. Lancet 1986; i: 1271.

36 Myren CJ, Wara P, Christensen JB. Somatostatin in the treatment of persisting pancreatic fistula - a report of two cases. Ann Chir Gynaecol 1986; 75: 295-7.

37 Hild P, Dobroschke J, Henneking K. Behandlung enterokutaner fisteln mit somatostatin. Klinikarzt 1986; 15: 24-9.

38 Prinz RA, Pickleman J, Hoffman JP. Treatment of pancreatic cutancous fistulas with a somatostatin analog. Am J Surg 1988; 155: 36-42.

39 Heij HA, Bruining HA, Verschoor L. A comparison of the effects of two somatostatin analogues in a patient with an external pancreatic fistula. Pancreas 1986; 1: 188-90.

40 Rodrigues CA, Lennard-Jones JE, Thompson DG, Farthing MJG. The effects of octreotide, soy polysaccharide, codeine and loperamide on nutrient, fluid and electrolyte absorption in the short bowel syndrome. Ailment Pharmacol Therap 1989: 3: 159-69.

41 Williams NS, Cooper JC, Axon ATR, King RFGJ, Baker M. Use of a long acting somatostatin analogue in controlling life threatening ileostomy diarrhoca. $\mathrm{Br} \mathrm{Med} \mathrm{J} \mathrm{1984;}$ 289: $1027-8$.

42 Nightingale JMD, Walker ER, Burnham WR, Farthing MJG, Lennard Jones JE. Does a somatostatin analogue (octreotide) reduce the need for parenteral fluids in patients with a short bowel? [Abstract] Gut 1988; 29: A1434-5.

43 Baxter JM, Jenkins SA, Day DW, et al. Effects of somatostatin and a long-acting somatostatin analogue on the prevention and treatment of experimentally induced acute pancreatitis in the rat. BrJ Surg 1985; 72: 382-5.

44 Schwedes U, Althoff PH, Klempa I, et al. Effect of somatostatin on bile-induced acute hemorrhagic pancreatitis in the dog. Horm Metab Res 1979; 11: 655-61.

45 Altimari AF. Sandberg L. Prinz RA. Comparison of a long-acting somatostatin analogue 
and trasylol for treatment of experimental pancreatitis. Can J Physiol Pharmacol 1986; 64: [suppl]; 72.

46 Limberg B, Kommerell B. Treatment of acute pancreatitis with somatostatin. $N$ Engl J Med 1980; 303: 284 .

47 Usdel KH, Schwedes U, Wdowinski J, et al. Untersuchungen zum kurativen effekt von somatostatin bei der akuten pankreatitis. Verh Dtsch Ges Inn Med 1979; 85: 591.

48 Usadel KH, Uberla KK, Leuschner U. Treatment of acute pancreatitis with somatostatin: Results of the multicentre double blind trial (APTS-study). Dig Dis Sci 1985; 30: 992.

49 Choi TK, Mok F, Zhan WH, Fan ST, Lai ESC, Wong J. Somatostatin in the treatment of acute pancreatitis: a prospective randomized controlled trial. Gut 1989; 30: 223-7.

50 Tamas G, Tulassay Z, Papp J, et al. Effect of somatostatin on the pancreatitis-like biochemical changes due to endoscopic pancreatography: preliminary report. Metabolism 1978; 27: [suppl]: 1333-6.

51 Bordas JM, Toledo V, Mondelo F, Rodes J. Prevention of pancreatic reactions by bolus somatostatin administration in patients undergoing endoscopic retrograde cholangiopancreatography and endoscopic sphincterotomy. Horm Res 1988; 29: 106-8.

52 Cicero GF, Laugier R, Sahel J, Manganaro M, Sarles H. Effects of somatostatin on clinical biochemical and morphological changes following ERCP. Ital J Gastroenterol 1985; 17: 265-8.

53 Talley NJ, Turner I, Middleton WRJ. Somatostatin and symptomatic relief of irritable bowel syndrome. Lancet 1987; ii: 1144.

54 O'Donnell LJD, Watson AJM, Cameron D, Davidson K, Wass JAH, Farthing MJG. Plasma somatostatin (SMS) concentrations in the irritable bowel syndrome (IBS) [Abstract] Gut 1989; 30: A714.

55 Long RG, Adrian TE, Bloom SR. Somatostatin and the dumping syndrome. Br Med J 1985 ; 290: $886-8$.

56 Reasbeck PG, Van Rij AM. The effect of somatostatin on dumping after gastric surgery: a preliminary report. Surgery 1986; 99: 462-8.

57 Primrose JN, Johnston D, Shaw C, Buchanan KD. Somatostatin analogue SMS 201-995 in the dumping syndrome effect on packed cell volume (PCV) blood glucose (BG) and plasma GI peptides. [Abstract] Gut 1987; 28: A1396.

58 Hopman WP, Wolberink RG, Lamers CB, Van Tongeren JH. Treatment of the dumping syndrome with the somatostatin analogue SMS 201-995. Ann Surg 1988; 207: 155-9.

59 Tulassay Z, Tulassay T, Tamas G. Benefit of somatostatin in dumping syndrome. Surgery 1988; 103: 130-1.

60 Santangelo WC, Dueno MI, Pike I, Estes BL, Krejs GJ. Clinical efficacy of the somatostatin analog 201-995 in the post-gastrectomy dumping syndrome. Gastroenterology 1987; 92: 1613.

61 Primrose JN, Bramley P, Johnston D. The use of octreotide (SMS 201-995) in the treatment of intractable dumping after vagotomy or gastrectomy [Abstract] Gastroenterology 1988: 94: A360.

62 Kraenzlin ME, Ch'ng JC, Wood SM, Bloom SR. Can inhibition of hormone secretion be associated with endocrine tumour shrinkage? Lancet 1983; ii: 1501.

63 Clements D, Elias E. Regression of metastatic vipoma with somatostatin analogue SMS 201-995. Lancet 1985; i: 874-5.

64 Santangelo WC, O’Dorisio TM, Kim JG, Severino G, Krejs GJ. VIPoma syndrome: effect of a synthetic somatostatin analogue. Scand J Gastroenterol 1986; 21: [suppl 119]: 187-90.

65 Redding TW, Schally AV. Inhibition of growth of the transplantable rat chondrosarcoma by analogs of hypothalamic hormones. Proc Natl Acad Sci USA 1983; 80: 1078-82.

66 Reubi JC. A somatostatin analogue inhibits chondrosarcoma and insulinoma tumour growth. Acta Endocrinol (Copenh) 1985; 109: 108-14.

67 Ch'ng JL, Anderson JV, Williams SJ, Carr DH, Bloom SR. Remission of symptoms during long term treatment of metastatic pancreatic endocrine tumours with long acting somatostatin analogue. Br Med J 1986; 292: 981-2.

68 Maton PN, O’Dorisio TM, O’Dorisio MS, et al. Successful treatment of pancreatic cholera with the long-acting somatostatin analogue SMS 201-995. Scand J Gastroenterol 1986; 21 : $181-6$.

69 Kvols LK, Moertel CG, O’Connell MJ, Schutt AJ, Rubin J, Hahn RG. Treatment of malignant carcinoid syndrome: evaluation of a long-acting somatostatin analogue. $N$ Engl $J$ Med 1986; 315: 663-6.

70 Levi S, Ellis M, Leung E, Adam E, Calam J, Hodgson H. Long-acting somatostatin in carcinoid syndrome. [Abstract] Gut 1988; 29: A714. 
71 Souquet JC, Chayvialle JA. Sassolas G, Partensky C. Biological and clinical efficacy of long-acting somatostatin analog (SMS 201-995) in secreting apudomas. Can J Physiol Pharmacol 1986; 64: [suppl] 64.

72 Buchanan KD, Johnston CF, Shaw C, et al. Somatostatin (SMS 201-995) therapy for gastrointestinal apudomas. Can J Physiol Pharmacol 1986; 64: [suppl]: 64.

73 Richter G, Stockmann F. The effect of food, pentagastrin and a somatostatin analoguc upon blood serotonin concentration in healthy subjects and paticnts with carcinoid tumours. Acta Endocrinol 1985; 108: [suppl 267]: 148.

74 Kvols LK, Martin JK. Marsh HM, Moertel CG. Rapid reversal of carcinoid crisis with a somatostatin analogue. $N$ Engl J Med 1985; 313: 1229-30.

75 Ellison EC, O’Dorisio TM, Benson GD. Modulation of functional gastrointestinal endocrine tumours by endogenous and exogenous somatostatin. Am J Surg 1986; 151: 66875 .

76 Kvols LK, Buck M, Moertel CG, et al. Treatment of metastatic islet cell carcinoma with a somatostatin analogue (SMS 201-995). Ann Intern Med 1987; 107: 162-8.

77 Longnecker SM. Remission of symptoms of chemotherapy-refractory metastatic insulinoma using octreotide. Drug Intell Clin Pharm 1988; 22: 136-8.

78 Osei K, O’Dorisio TM, Frank BH. Chronic effects of somatostatin (SMS) analog (201-995) may be independent of suppression of endogenous insulin secretion. [Abstract] Clin Res 1985; 33: 827A.

79 Ch'ng JL, Anderson JV, Williams SJ, Carr DH, Bloom SR. Remission of symptoms during long term treatment of metastatic pancreatic endocrine tumours with long-acting somatostatin analogue. $\mathrm{Br}$ Med $\mathrm{J}$ 1986; 292: 981-2.

$80 \mathrm{Kvols} \mathrm{LK}$. Buck M. Moertel CG, et al. Treatment of metastatic islet cell carcinoma with a somatostatin analogue (SMS 201-995). Ann Intern Med 1987; 107: 162-8.

81 Schrezenmeir J, Plewe G, Sturmer W, et al. Treatment of APUDomas with the long-acting somatostatin analogue SMS 201-995: investigations of therapeutic use and digestive side effects. Scand J Gastroenterol 1986; 21: [suppl 119]: 223-7.

82 Kvols L, Moertel C, Schutt A, O'Connell M, Rubin J, Hahn R. Treatment of malignant neuroendocrine syndromes with a long-acting somatostatin analogue (SMS 201-995). Can J Physiol Pharmacol 1986; 64: [suppl]: 10.

83 Koelz A, Kraenzlin M, Gyr K, et al. Escape of the response to a long-acting somatostatin analogue (SMS 201-995) in patients with VIPoma. Gastroenterology 1987; 92: 527-31.

84 Buck M, Kvols LK, O'Dorisio TM. Rebound hypergastrinemia after cessation of a somatostatin analoguc (SMS 201-995). Am J Med 1987; 82 (5B): 92-5.

85 Lamberts SW. Non-pituitary actions of somatostatin. A review on the therapeutic role of SMS 201-995 (sandostatin). Acta Endocrinol 1986; 112: [suppl 276]: 41-5. 